\title{
Innovation Input-Output Analysis of African Countries
}

\author{
Alida Magakam Tchamekwen Zhao Xicang \\ School of Finance and Economics, Jiangsu University China \\ No. 301 Xuefu Road, Zhenjiang, Jiangsu, P.R.China 212013
}

\begin{abstract}
Given the importance of innovation in global competitiveness, this study aims to analyze the relationship between innovation input-output in African countries from 2009 to 2017, determining the degree of significance of each input on the output. With data collected from the Global Innovation Index, an Econometric random Fixed effect model was run revealing a negative insignificant effect of institutions on innovation, a positive insignificant effect of human capital on innovation, a positive insignificant effect of infrastructures on innovation, a positive significant effect of market sophistication on innovation, and finally a positive significant effect of business sophistication on innovation.

Keywords: Innovation, input-output, African countries.

DOI: $10.7176 / \mathrm{JAAS} / 54-09$

Publication date: April $30^{\text {th }} 2019$

\section{Introduction}

Globalization has pushed economies and organizations beyond national borders. Competing in a global environment, it becomes peremptory to develop competitive advantage in order to face national and international challenges. Innovation comes to be a way for countries to achieve sustainable development (Romer, 1986;Hail and Jones,1999; Ahlstrom, 2010)and participate more efficiently in the global value chain .For developed and developing economies innovation is a fundamental driver of competitiveness (Cornell University,2014).African economies are aware of this, recently innovation is at the heart of Governments and organizations debates. African leaders have over the past years reiterated their determination to end poverty, improve social life and economic stability. Innovation has become a new set of hope for Africa to finally integrate the global economy dynamic, and address the new global business world competition. Innovation offers opportunity to definitely embrace the path towards industrialization, Competitiveness, national and cross border performance, as it also generates technological progress. The innovation phenomenon contribute to stimulate growth and productivity through knowledge creation and diffusion (OECD, 2010), and value creation(Deeds, DeCarolis \& Wombs, 2000). According to the OSLO manual (OECD and Eurostat, 2005), innovation is the creation of new products, business structure, processes, and methods. Schumpeter studies reveals that the concept embodies marketing innovation, organizational innovation, process innovation, product innovation, and input innovation. From the Schumpeterian idea, innovation is an engine growth that comes from entrepreneurial activities with investment in significant factors such R\&D and many others with the expectation of getting economical outcomes. The second Schumpeterian idea is that to be innovative; entrepreneurs need to be in an incentive environment in which political institutions, economic policies, financial structures, and infrastructures constitute the key determinants. Indeed innovation is what enhance competition and help to improve products and services. But taking advantage of innovation and seizing the opportunities it comes with depends on the ability of economies to implement and develop potent inputs, and their capacity of using these inputs to obtain outputs. The Global innovation index is an annual ranking of economies of the world regarding their ability to conduct innovations successfully. The index embodies two broad sub-indices, the innovation input index measuring innovation capacity (factors promoting innovation) and the innovation output index measuring the results. The paper aims to use the Global innovation Index data to analyze the innovation inputs and outputs relation in 28 African countries with precision about the level of significance of each input on the output.

This paper is structured as follow: First, we present a literature review of the relationship between institutions, human capital, infrastructure, market, and business sophistication and innovation. The second part introduces our data source, variables and precision of econometric model to be used. Then come the third part exhibiting our results and assumptions; this drives us to the formulation of suggestions followed by the conclusion.
\end{abstract}

\section{Determinants of innovation}

The existing literature emphasizes some critical factors of innovation. The Global Innovation Index to establish more visibility identifies fives determinants of innovation: Political institutions, Human resources, business sophistication, market sophistication, and general infrastructures. 


\subsection{Political institutions}

Numbers of studies have focused on explaining how political institutions affect micro and macro level innovation activities. Political stability is defined as constant application of rules and regulations within a continuous institutional environment (Waguespack, Birnir and Schroeder 2005). While political instability refers to unstable governments and changeful policies leading to social conflicts and violence (Alesina et al., 1996). Africa and particularly Sub-Saharan Africa has been for years undergoing socio-political instabilities, some of the major political issues of African economies are the following: Socio-political instability, corruption, and breaches of laws and regulations. Indeed, African countries are known has been the most corrupted in the world (Whitehead 2001). As many countries still go through multiparty and democracy challenges, this tends to impact the innovation activities. At the firm micro level (Sorin M.S. Krammer) finds that political instability have a significant negative effect on firms product and process innovation by reducing the amount of investments. Political instability also leads to reduction of skilled human resources (Collier and Duponchel, 2003), reduction of firm's innovation capabilities due to the uncertainty in customers consumption and choices (Schmookler, 1962) and drop of firm level of productivity (Klapper, 2013). In contrast, political stability is a critical driver of products, process innovation (Courvisanos, 2009) and patenting efforts (Waguespack et al., 2005). At the macro level, studies have shown that stable institutions positively affect innovation outputs (Tebaldi and Elmslie 2006) such knowledge accumulation (Rodrik, 2000). While political instability will make it hard for countries to attract foreign direct investments (Allard, G., Martinez, C. and Williams, C., 2012).

\subsection{Human capital and innovation}

Physical interactions within individuals are a key factor to generate, adopt and implement innovations; all the human resources must be integrated in the innovation processes (Morcillo, 1997). Human capital is defined by (Becker, 1964) as being a set of individual skills, knowledge and abilities. (Dakhli \& De Clercq, 2004) Argue that the human capital factor is a key engine of competitive advantage both at the micro and macro level. Defining Individual schooling as the schooling level of individual in a nation or a firm, a good level of education will then enhance knowledge absorption (cf. Cohen \& Levinthal, 1990), and will increase the individual capacity in creating, processing and transmitting information (Nelson \& Phelps, 1966). (Liu \& Buck (2007) in their analysis found that education in China positively affects innovation output. At the firm level employees, effective training has a positive effect on innovation outputs (Schneider et al. 2010); Mahemba \& Bruijn, 2003). Training can lead to better skills and knowledge that are vital for innovation (Mabey and Salaman, 1995). (Mark and Akhtar, 2003) find that there is positive relationship between the employees training and the innovations outcomes. In contrast, Robson et al. (2009) argue that in the case of Ghana there is not a positive relation between training and innovation. Employment security system may also have a positive effect on innovation activities (Jackson et al.1989), as employees with stable job position may feel more secured in providing needed efforts to conduct innovations. Human resources Managers also play a vital role in innovation activities since they are responsible for choosing the right innovation model for their entities and finding effective strategies for the resources allocation.

\subsection{Infrastructure}

In the context of globalization, Africa is facing the challenges of competitiveness. One of the determinants of this competitiveness is the development of different types of infrastructure, as they are drivers of modern economies growth (Stewart, 2010). The term infrastructures refers to various kinds of physical structures that entities use as inputs of the production of goods and services (Chan et al., 2009)Thus, the development of innovation infrastructures is essential to ensure better economic performance of African countries, and to strengthen collaboration in the field of innovation in particular by improving the quality of research institutions, the quality of education systems, energy supply, communication, and logistics infrastructures. Infrastructures are key drivers of innovation as they facilitate information exchange, better collaboration, and knowledge diffusion. Foundations can lead to reducing production costs and increasing productivity. They also extend the geographic reach of markets and provide opportunities to develop new products and services, new processes and new business models. (Impacts of ICT, Published on Innovation Policy Platform ICT).Mobile phone beside helping to create jobs can meanwhile enhance economic growth through better information exchange, new markets, and cost reduction and can even be used as substitute of costly transportation in rural zones of Africa (Kyem,P. A. and LeMaire, P . K., 2006).

\subsection{Business sophistication}

Business sophistication refers to the quality of a country's overall business network and the individual firm's operations and strategies. According to (Porter \& Schwab, 2008, p.8) the presence of a value chain and the production of unique and sophisticated products all lead to sophisticated and modern business processes. In their research, Ali Aghajani, Hassan \& Jamalian, Ahmad \& Mahbanooei, Bahareh, (2014) argue that business 
sophistication is a critical factor of economic growth, analyzing the impact of business sophistication on Iran regional competitiveness, they find that production process sophistication, nature of competitive advantage and state of clusters are the key elements. For Razavi, S. M., Abdollahi, B., Ghasemi, R., \& ShaPie, H. (2012) the level of a country's business networks and the extent of interactions within entities of the industry can contribute to create more significant opportunities for innovation.

\subsection{Market sophistication}

Market sophistication of an economy can be analyzed and understood through aspects such access to loan and foreign direct investments. Easy access to credit can help firms to acquire external knowledge, to apply license and patent for their new products (Çaðatay Bircan, 2015), he continues arguing that firms tend to be more innovative in locations with less credits constraints. Pierre-Richard Agénor, Otaviano Canuto, and Michael Jelenic (2014) pointed that the most innovative firms are those granted with loans. Focusing on the market size, Young (1998) supports that the larger an economy is, the greater are the efforts to develop different solutions to address the same issue. With researches on the role of demand size on innovation, Schmookler $(1962,1966)$ found that a large demand can enhance innovation activities since entities will tend to perceive high profit related to the demand growth.

Increasing studies highlight positive impacts of foreign subsidies on innovation activities in the host country (Birkinshaw and Ridderstrale 1999, Yamin and Otto, 2004). With interest on the Spanish manufacturing sector, Francisco García, Byungchae Jin and Robert Salomon (2012) conducted an analysis of 1799 Spanish firms from 1990 to 2002 and their result suggested the existence of negative correlation between foreign direct investment and local Spanish firms innovative performance. There could be some mechanisms through which foreign direct investment can boost the host country's innovation performance. First, increased competitive pressure due to the presence of foreign competitors on the local market is a key engine that will push local firm toward conceptualization and introduction of new products and services. Second, through knowledge transfer, host country can get benefits of learning from foreign companies.

\section{Methodology}

For a better understanding of innovation activities in Africa, we conduct a quantitative analysis of the innovation inputs outputs relation in African countries. In order to carry out our study, data were collected in annual Global Innovation Index reports for 28 African countries from 2009 to 2017. Recourse to the Global Innovation Index for data collection is because it provides a yearly report on countries innovation performance. In the reports countries are ranked according to their innovation input-output scores, countries innovation deeds are rated over 100 , as a near to 100 score implies high performance. Our sample period was chosen based on data availability for the countries subjects. Our sample group is constituted by 28 African countries: Gambia, Mali, Senegal, Nigeria, Benin, Burkina Faso, Ghana, Ivory cost, Niger, Togo, Cameroon, Burundi, Rwanda, Kenya, Tanzania, Uganda, Ethiopia, Mozambique, Zimbabwe, South Africa, Zambia, Botswana, Namibia, Egypt, Algeria, Morocco, Tunisia and Sudan. The global innovation index framework present five innovation input sub-index and two innovation output sub-index. The input sub-index comprises Institutions, Human capital, Infrastructures, Market sophistication, and Business Sophistication. The output sub-index contains Knowledge and Creative output. Our analysis took into account the five input sub-index elements representing our independent variables and only one of the output sub-indexes representing our dependent variable. In this study, we run an econometric analysis of the variables to find the degree of significance of each of the five independent variables on the single dependent variables. In other words, the analysis aims to determinate how in the 28 African countries institutions, human capital, infrastructures, market sophistication, and business sophistication affect knowledge creation.

Dependent variable

Y knowledge creation

Independent variables

$\mathrm{X} 1$ institutions

X2 human capital

$\mathrm{X} 3$ infrastructures

X4 market sophistication

X5 business sophistication

First, we run a simple multiple regression model (OSL), for more relevance we go further running the Fixed and Random effect model with the Hausman test carried out to find out which one of the Fixed effect or random effect is the most appropriate for our panel data. At the end, we proceed the Lagrangian multiplier test to verify the relevance between OSL regression model and random effect. 


\section{Result}

Table 1: OLS regression

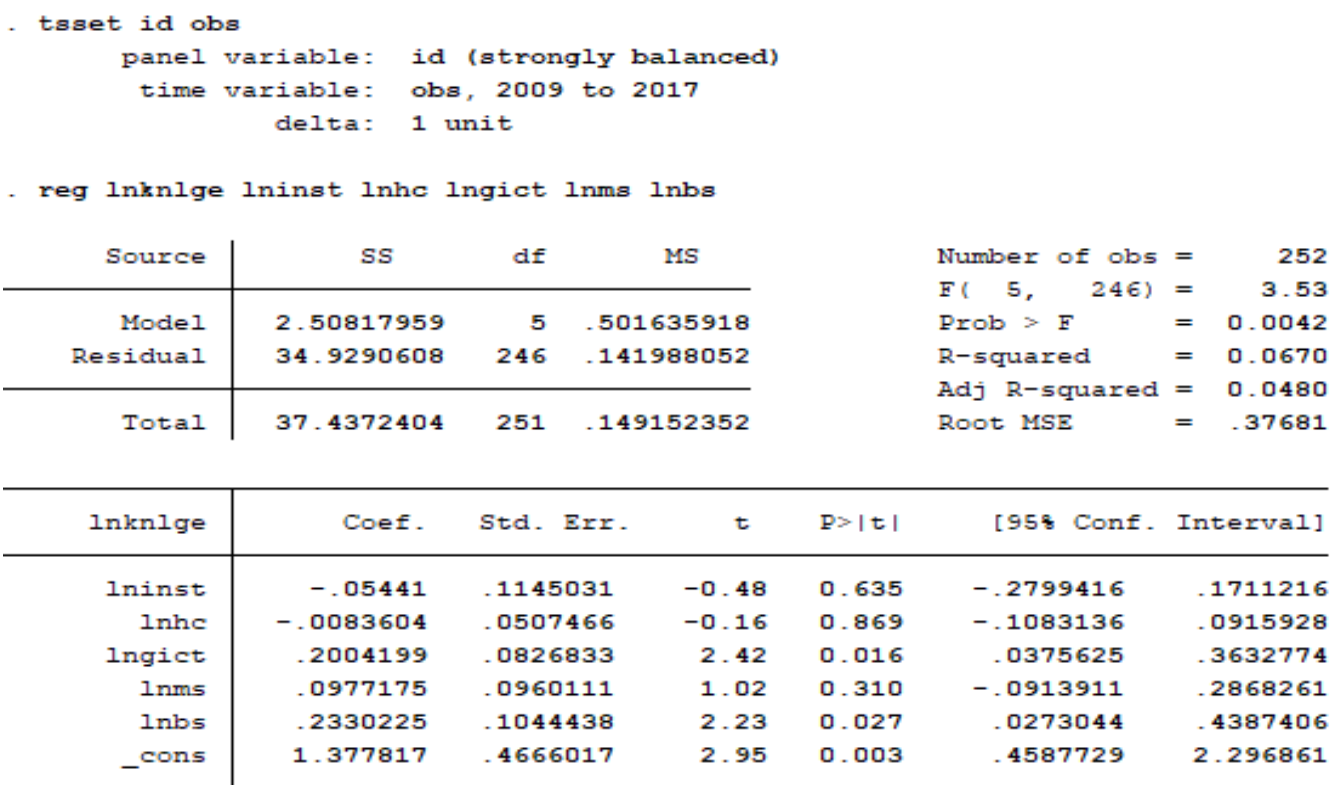

Table 1 is an exhibit of the OSL regression, the output shows :

Positive insignificant effect of market sophistication on innovation

Positive significant effect of business sophistication on innovation

Negative insignificant effect of human capital on innovation

Negative insignificant effect of institutions on innovation

Positive significant effect of infrastructures on innovation

Table 2: Fixed effect regression

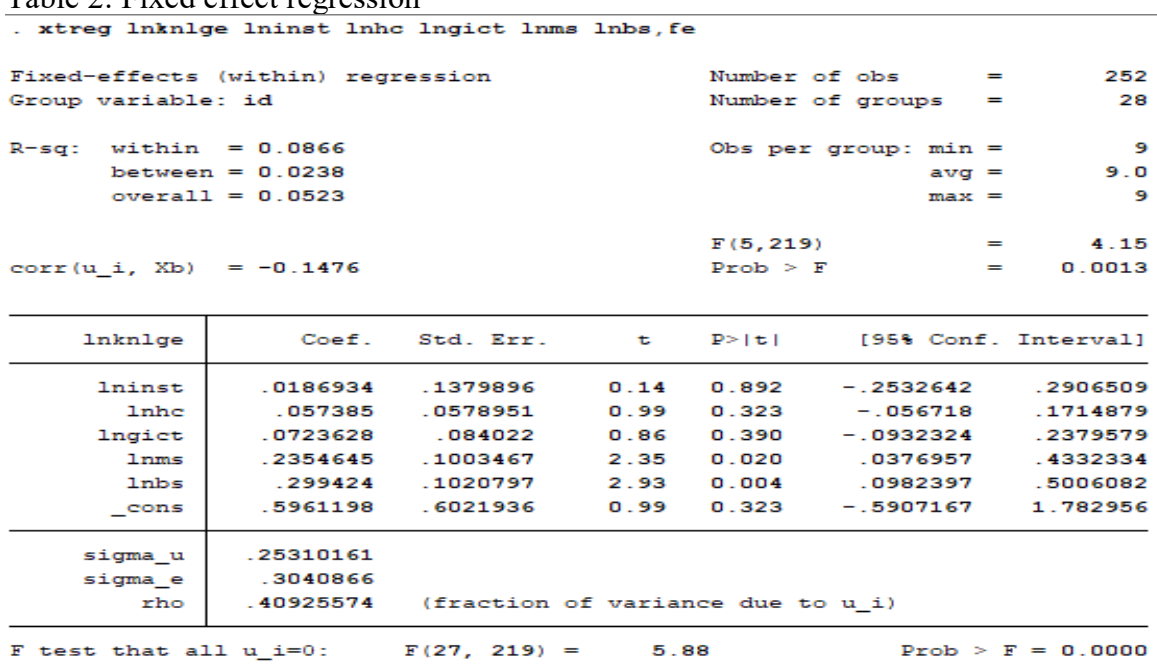

- estimates store fe

Table 2 presents the outcome of the fixed effect model suggesting:

Positive significant effect of business sophistication on innovation

Positive significant effect of market sophistication on innovation

Positive insignificant effect of human capital on innovation

Positive insignificant effect of infrastructures on innovation

Positive insignificant effect of institutions on innovation 
Table 3: Random effect regression

- xtreg lnknlge lninst lnhc lngict lnms lnbs, re

Random-effects GLS regression

Group variable: id

R-sq: within $=0.0854$

between $=0.0305$

overall $=0.0572$

$\begin{array}{rlr}\text { Number of obs } & =252 \\ \text { Number of groups } & = \\ \text { Obs per group: } \min & = \\ \text { avg } & = & 28 \\ \max & = & 9.0 \\ & \end{array}$

$\begin{array}{llr}\text { Wald chi2 (5) } & = & 20.62 \\ \text { Prob }>\text { chil } & = & 0.0010\end{array}$

$\operatorname{corr}\left(\mathrm{u}_{-} \mathrm{i}, \mathrm{x}\right)=0$ (assumed)

0.0010

\begin{tabular}{r|rrrrrr}
\hline lnknlge & Coef. & Std. Err. & $z$ & P $>|z|$ & [958 Conf. Interval] \\
\hline lninst & -.0083037 & .1252106 & -0.07 & 0.947 & -.2537119 & .2371046 \\
lnhe & .0401254 & .0528347 & 0.76 & 0.448 & -.0634287 & .1436795 \\
lngict & .100067 & .0793847 & 1.26 & 0.207 & -.0555242 & .2556581 \\
lnms & .1993937 & .0950474 & 2.10 & 0.036 & .0131043 & .3856831 \\
lnbs & .2760328 & .0978988 & 2.82 & 0.005 & -0841546 & .467911 \\
_cons & .8689509 & .5360503 & 1.62 & 0.105 & -.1816884 & 1.91959 \\
\hline sigma_u & .22684643 & & & & & \\
sigma_e & .3040866 & & & & & \\
rho & .35753514 & (fraction of variance due to u_i) &
\end{tabular}

estimates store re

Table 3 is the result of the Random effect model, here we have:

Positive significant effect of business sophistication on innovation

Positive significant effect of market sophistication on innovation

Positive insignificant effect of human capital on innovation

Positive insignificant effect of infrastructures on innovation

Negative insignificant effect of institutions on innovation

Table 4: Hausman test

hausman fe re

\begin{tabular}{r|cccc} 
& \multicolumn{2}{c}{ Coefficients } & & \\
& fe & $\begin{array}{c}\text { (B) } \\
\text { re }\end{array}$ & $\begin{array}{c}\text { (b-B) } \\
\text { Difference }\end{array}$ & $\begin{array}{c}\text { sqrt (diag (V_b-V_B ) } \\
\text { S.Z. }\end{array}$ \\
\hline Ininst & .0186934 & -.0083037 & .026997 & .0579951 \\
lnhc & .057385 & .0401254 & .0172596 & .0236715 \\
lngict & .0723628 & .100067 & -.0277042 & .0275274 \\
lnms & .2354645 & .1993937 & .0360708 & .0321786 \\
lnbs & .299424 & .2760328 & .0233912 & .0289149 \\
\hline
\end{tabular}

$\mathrm{b}=$ consistent under $\mathrm{Ho}$ and $\mathrm{Ha} ;$ obtained from xtreg

$\mathrm{B}=$ inconsistent under $\mathrm{Ha}$, efficient under Ho; obtained from xtreg

Test: Ho: difference in coefficients not systematic

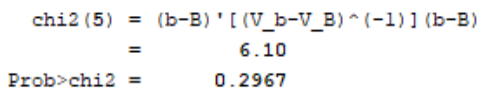


Table 5: Breush and Pagan Lagrangian multiplier test for random effect xttesto

Breusch and Pagan Lagrangian multiplier test for random effects

lnknlge $[i d, t]=X b+u[i d]+e[i d, t]$

Bstimated results:

\begin{tabular}{r|cc} 
& Var & sd $=$ sqrt (Var) \\
\hline lnknlge & .1491524 & .3862025 \\
$\mathrm{e}$ & .0924687 & .3040866 \\
$\mathrm{u}$ & .0514593 & .2268464
\end{tabular}

Test: $\operatorname{Var}(\mathrm{u})=0$

$$
\begin{aligned}
\text { chibar2 }(01) & =110.72 \\
\text { Prob }>\text { chibar2 } & =0.0000
\end{aligned}
$$

In table 4 we perform the Hausman test to find out the most suitable model within fixed effect model and Random effect model. Our results show Prob $>$ chi2 value $=0.2967$ which is $>0.05$; we can thus say the model that better fits our panel data analysis is the Random effect model. But for more relevance, we carry out in table 5 the Breusch-Pagan Lagrangian Multiplier test to make sure the Random effect should be retained rather than the OLS regression. The result show Prob $>$ chi 2 value $=0.0000$. Because our value is $<0.05$ here we tend to say that null hypothesis of homoskedasticity is rejected, and heteroskedasticity assumed as there are significant differences across countries, and this lead to conclude that effectively the best model here for us to use is the Random effect model exhibited in table 3.

Table 3 is the exhibit of the Random effect model, model where lnKnlge represents the dependent variable knowledge creation, lninst represents institutions, lnhc represents human capital, lngict represents general infrastructures, lnms represents market sophistication, and lnbs represents business sophistication. The output of this shows an insignificant negative impact of institutions on innovation output (knowledge creation). this assertion is justified by the outcome of $\mathrm{P}$ value $0.947>0.1$, and the $\mathrm{Z}$ value $-0.07<2$. Here we stand that in African countries institutions do not significantly influence innovation. However the result shows a negative coefficient- 0.0083037 , and this means that when that each time one unit the level of institutions in African countries will decrease, this will simultaneously lead to a decrease of knowledge by -0.0083037.Indeed most of African countries are experiencing socio-political instability. African institutions are fragile and even week, with dictatorial regimes and corruption. Governments do not come out with effective programs that could be incentive for innovation and those in place are usually not carried out till the end success due to funds embezzlement. Business environment is also another obstacle to innovation in Africa as procedures to start a business are charged with high constraints. Besides, intellectual property rights are not embodied in a way to encourage innovative mindset; patent application is charged with high cost that makes it hard for some actors to obtain protection for their new ideas or new products.

As many African countries invest less in research \& development (average of $0.7 \%$ of the GDP), with relatively poor education system, this explain the limitations of human capital for being a key driver of innovation in Africa. Indeed the model highlights a positive insignificant effect on knowledge creation with a $\mathrm{P}$ value $0.448>0.1$ and $\mathrm{Z}$ value $0.76<2$. This allows us to stand that in Africa human capital does not yet fulfill a considerable impact on innovation performance but with a positive even small coefficient $=0.0401254$ we assume that an increase of one unit of human capital performance will create gain of 0.0401254 in innovation output. African organizations still do not perceive the important role of research as many of them in their internal structure do not integrate research units. Most of research initiatives are taken and financed by governments but still not enough.

Infrastructure development play a tremendous role in economic growth, and many countries has put efforts and great investments in infrastructures projects in order to better drive innovations activities. But the African continent still lack relevant infrastructures. Africa is the continent least endowed with infrastructure. The continent does not have enough roads, railways, production and transmission networks, water purification facilities and telecommunication facilities. We can still witness water, electricity and internet shortage during days and even weeks. Regardless of the type of infrastructure, Africa suffers from under-equipment, due in part to the dilapidated colonial or post-colonial infrastructure that has been poorly maintained and partly to underinvestment by governments. in Africa, sometimes because of a lack of budget, sometimes because of a lack of medium-term political and economic vision. Our result suggests that African countries innovation output performance has a small positive insignificant connection with to their infrastructure development. Indeed 
analysis shows a $\mathrm{P}$ value $0.207>0.1$ and $\mathrm{Z}$ value $1.26<2$. With a coefficient $=0.100067$ this means that an increase of one unit of infrastructure will increase 0.100067 of innovation deeds.

In our output appears a significant positive effect of market sophistication on innovation, with a $\mathrm{P}$ value $0.036<0.1$ and $\mathrm{Z}$ value $2.10>2$, we tend to accept the alternative hypothesis and reject the null hypothesis to say that when level of market sophistication will increase by one then innovation performance will increase by 0.1993907.Africa attracts increasingly numbers of foreign projects and investments. Africa's innovation performance takes profits from FDI through knowledge and technology learning from foreign subsidies. Another positive aspect is the increasingly efforts of governments to facilitate credits to the private sector since many actors do not necessarily have founds to finance their innovation practices.

Business sophistication is also shown as positively impacting innovation, here we have $\mathrm{P}$ value $0.005<0.1$ and $\mathrm{Z}$ value $2.82>2$; thus we reject the null hypothesis, and we accept the alternative hypothesis to say when business sophistication increase by one simultaneously innovation output will increase by 0.2760328 .

\section{Policies implication}

As our analysis reveal a negative insignificance impact of institutions on innovation in Africa, it's important that African government improve the political environment to ensure intellectual property right protection. Anticorruption programs already implemented into many countries have to be more effective, and efficient. Government has to implement patent application facility programs, and the most important is to simplify procedures for start-up. All these measures will help to develop and encourage innovation mindset. It's also urgent for countries to invest more in tertiary education with science, technology, and engineering programs, governments can seek international exchange partnership with international universities to diversify knowledge sources. Efforts have to be done in terms of R\&D investment countries need to implement sustainable funding systems for science and R\&D. Those Systems have to be competitive and responsive for reorienting the research ecosystem to focus on sustainable technologies and innovations. Relevant infrastructures programs have to be developed. Indeed infrastructures issue is urgency in Africa, but governments need to determine what infrastructure are the most necessary for innovation before taking actions. The private sector has to be involved in the process, and public-private Corporation must be build up in terms of infrastructure investment. As Market sophistication appears to be have positive impact on Africa innovation performance, governments has to improve investment environment to attract more FDI and encourage partnership between foreign subsidies and local enterprises so that they can absorb more knowledge.

\section{Conclusion}

This work aimed to analyze the relationship between innovation input-output in Africa. The literature has shown that political stability is likewise to foster innovation while institutions instability will have a perverse effect. Studies have also pointed out that R\&D activities and education system are key drivers of innovation. It appears that infrastructures, foreign direct investment, credit to private sector and business sophistication all play a determinant role in effort to create new product and services. With evidence from 28 African countries data all collected from the Global innovation index from 2009 to 2017, our results has shown that institutions does have an insignificant negative impact on innovation performance in Africa. While the human capital factor appeared to be insignificant, infrastructures shown a small positive and insignificant effects. But difference comes out with market sophistication and business sophistication both positively and significantly impacting Africa's innovation performance. We end up showing that efforts have to be made to stabilize political environment and institutions that will secure innovators. Human capital and infrastructures also need a special treatment while market sophistication and business sophistication need to be strengthen.

\section{References}

Allard, G., Martinez, C. and Williams, C. (2012). Political instability, pro-business market reforms and their impacts on national systems of innovation. Research Policy, 41(3): 638-651.

Alesina, A. and Perotti, R. (1996). Income distribution, political instability, and investment. European Economic Review, 40(6), pp.1203-1228

Ali Aghajani, Hassan \& Jamalian, Ahmad \& Mahbanooei, Bahareh. (2014). Investigating the ImportancePerformance Matrix of Business Sophistication indices for Iran in competition of Regional Countries (In Persian).

Arvanitis, Spyros \& Loukis, E \& Diamantopoulou, Vasiliki. (2011). The impact of Different Types of ICT on Innovation Performance of Greek Firms Becker, G. (1964). Human Capital. New York: National Bureau of Economic Research

Biekinshaw, J. and Riddersstrale , J. (1999) process study of subsidiary initiatives in multinational corporations. International Business Review, 8, 149- 180.

Cagatay Bircan. (2015).Does access to credit help boost innovation https://www.weforum.org/agenda Chan, C., 
Forwood, D., H. Roper, and C. Sayers (2009) 'Public Infrastructure Financing: An International Perspective', Productivity Commission Staff Working Paper.

Cohen, W. M., \& Levinthal, D. A. (1990). Absorptive Capacity?: A New Perspective on Learning and Innovation. Administrative Science Quarterly, 35, 128 - 152

Collier, P. and Duponchel, M. (2013). The Economic Legacy of Civil War: Firm-level Evidence from Sierra Leone. Journal of Conflict Resolution, 57(1), pp.65-88.

Cornell University, INSEAD \& WIPO , (2014). The Global Innovation Index 2014,Geneve:The Human Factor in Innovation.

Courvisanos, J. (2009). Political aspects of innovation. Research Policy, 38(7), 1117-1124.

Dakhli, M., \& De Clercq, D. (2004). Human capital, social capital, and innovation: a multi-country study. Entrepreneurship \& Regional Development, 16(2), 107-128.

Deeds, David \& De Carolis, Donna \& Coombs, Joseph. (2000). Dynamic capabilities and new product development in high technology ventures: An empirical analysis of new biotechnology firms. Journal of Business Venturing. 15. 211-229. 10.1016/S0883-9026(98)00013-5.

Francisco García, Byungchae Jin, Robert Salomon, Does inward foreign direct investment improve the innovative performance of local firms? Pages 231-244,ISSN 0048-7333,https://doi.org/10.1016/j.respol 2012.06.005.

Jackson, S.E., Schuler, R.S. and Rivero, J.C. (1989), “Organizational characteristics as predictors of personnel practices”, Personnel Psychology, Vol. 42, pp. 727-86.

Kabanda, Gabriel. (2012). The Impact of ICTs on Innovative Sustainable Development in East and Southern Africa. 10.5772/36437.

Klapper, L. F., Richmond, C., \& Tran, T. (2013). Civil conflict and firm performance: evidence from Cote d'Ivoire. World Bank Policy Research Working Paper, (6640).

Kyem, P.A. and LeMaire, P.K. (2006), "Transforming recent gains in the digital divide into digital opportunities: Africa and the boom in mobile phone subscription", The Electronic Journal on Information Systems in Developing Countries, EJISDC (2006)28, Volume 5, pages 1-16.

Liu, X., \& Buck, T. (2007). Innovation performance and channels for international technology spillovers: Evidence from Chinese high-tech industries. Research Policy, 36(3), 355-366. doi:10.1016/j.respol.2006.12.003 .

Mabey, C. and Salaman, G. (1995), Strategic Human Resource Management, Blackwell, London.

Mahemba, C. M., \& Bruijn, E. J. De. (2003). Innovation Activities by Small and Medium-sized Manufacturing Enterprises in Tanzania. Creativity and Innovation Management, 12(3), 162-173. doi:10.1111/14678691.00279.

Mark, S.K.M. and Akhtar, S. (2003), "Human resource management practices, strategic orientations, and company performance: a correlation study of publicly listed companies", Journal of American Academy of Business, Vol. 2 No. 2, pp. 510-5.

Nelson, R. R., \& Phelps, E. S. (1966). Investment in Humans, Technological Diffusion , and Economic Growth. The American Economic Review, 56(1/2), 69-75.

OCDE (2010), Mobiliser l'innovation pour affermir la croissance et relever les défis planétaires et sociaux .

OCDE et Eurost (2005); Manuel d'Oslo - Principes directeurs pour le recueil et l'interprétation des données sur l'innovation, OCDE, Paris.

Pierre-Richard Agénor, Otaviano Canuto, and Michael Jelenic. (2014). Access to Finance, Product Innovation, and Middle-Income Growth Traps.

Razavi, S. M., Abdollahi, B., Ghasemi, R., \& ShaPie, H. (2012).Relationship between Innovation and Business Sophistication: A Secondary Analysis of Countries Global Competitiveness. European Journal of Scientific Research,79(1),29-39.

Robson, P. J. a., Haugh, H. M., \& Obeng, B. A. (2009). Entrepreneurship and innovation in Ghana: enterprising Africa. Small Business Economics, 32(3), 331-350. doi:10.1007/s11187-008-9121-2.

Rodrik, D. (1991). Policy uncertainty and private investment in developing countries. Journal of Development Economics, 36(2), pp.229-242.

Schmookler, J. (1962). Economic Sources of Inventive Activity. Journal of Economic History, 22(1), pp.1-20.

Schmookler, Jakob 1962. Economic Sources of Inventive Activity. Journal of Economic History 22, 1-20.

Schmookler, Jakob 1966. Invention and Economic Growth, Cambridge, MA: Harvard University Press.

Schneider, L., Günther, J., \& Brandenburg, B. (2010). Innovation and skills from a sectoral perspective: a linked employer-employee analysis. Economics of Innovation and New Technology, 19(2), 185-202. doi:10.1080/10438590902872887.

Stewart, J. (2010) 'The UK National Infrastructure Plan 2010', European Investment Bank Papers: Public and Private Financing of Infrastructure.

Sorin M.S. Krammer, Coping with Politic Instability: Firm Innovation in Sub-Saharan Africa. 
Tebaldi, E., and Elmslie, B. (2008). Do institutions impact innovation? Available: http://mpra.ub.unimuenchen.de/8757.

Waguespack, D., Birnir, J. and Schroeder, J. (2005). Technological development and political stability: Patenting in Latin America and the Caribbean. Research Policy, 34(10), pp.1570-1590.

Whitehead, M., M. (2001) , "Fighting Corruption in Sub-Saharan Africa : Can We Win the War?" Price waterhouse Coopers, Kenya.

Yamin, M. and Otto, J. (2004) Patterns of knowledge flows and MNE innovative performance, Journal of International Management, Vol. 10, pp. 239- 258.

Young, Alwyn 1998.Growth without scale effect. Journal of Political Economy 106 